\title{
Brian Friel's Translations: A Bourdieusian Reading
}

\author{
Hossein Pirnajmuddin \\ English Department, Faculty of Foreign Languages, University of Isfahan, Iran \\ Elham Heidari \\ English Department, Faculty of Foreign Languages, University of Isfahan, Iran
}

\begin{abstract}
Brian Friel is one of the most eminent figures in contemporary Irish drama. In his plays, he addresses the issues of language, culture, education, power, politics and myth. He is also mostly regarded as a postcolonial writer, since he is concerned with colonial and postcolonial contexts in which language and cultural clash are dominant factors. Pierre Bourdieu, a French sociologist, as one of the theorists in cultural studies mentions the dynamics of power relations in social life through such ideas as capital, habitus, field, symbolic violence, etc. Therefore Bourdieu's theories regarding class, culture and language are applicable. The focus of this article is to analyze Friel's plays in the light of Bourdieu's sociological notions. According to Bourdieu, there are different types of capital (cultural, economic, social and symbolic) which distinguish every individual's position in society and in relation to other individuals. . For instance in Translations, the play which is going to be analyzed, the Irish characters who speak their native language (Gaelic) try to learn English in order to get linguistic capital and form a prestige or social status for themselves.
\end{abstract}

\section{Index Terms - Translations, Bourdieu, cultural capital, symbolic capital, power}

Brian Friel is one of the most eminent figures in contemporary Irish drama. In his plays, he addresses the issues of language, culture, education, power, politics and myths. As he is mostly regarded as a postcolonial writer, critics have analyzed his plays from the postcolonial perspective. Csilla Bertha in "Brian Friel as Postcolonial Playwright," calls Friel a postcolonial writer:

$\mathrm{He}$ is postcolonial in the sense that, feeling in his nerves the responsibility for the community he comes from, and worrying about the survival not only of individual but also of cultural values in the value-free modern/postmodern world, Friel continually faces the consequences of colonization, the experience that so deeply determined the formation of the modern Irish history, society and identity. His writing has been concerned with the nuances of both personal and cultural-national identity and its relation to colonial dispossession, issues of home, language, tradition, the working sof private and public memory $\square$ all issues that inform postcolonial consciousness. Apart from thematic considerations, Friel has also experimented with the techniques of fragmenting, subverting and destabilizing conventional stage realism favored by postcolonial drama. (Bertha, 2006, p. 154)

He dramatizes the conditions of Irish society through small communities which serve as microcosms representing the Irish society. Translations, as one of Friel's most outstanding works, addresses most of the above-mentioned issues, especially the interconnection of language, culture and power. Thus Pierre Bourdieu's theories about the relation between individuals, which he calls social 'agents,' and the position they try to gain, is applicable to Translations. According to Bourdieu in the process of socialization, agents struggle for different capitals (cultural, social, linguistic, economic and symbolic) which guarantee power and social status. The aim of this article is to analyze Friel's play in the light of Bourdieu's main sociological notions, viz. capital, habitus, bodily hexis, misrecognition and field.

Before starting the discussion of the play, a brief introduction to Bourdieu's relevant theories follows. Bourdieu believes that there are different types of capital which distinguish every individual's position in society in relation to other individuals. Bourdieu's major capitals or values are cultural, social, symbolic, linguistic and economic.

Cultural capital is the desire for something which is culturally valued and is worth accumulating in order to gain a higher social status. As Jen Webb puts it:

Cultural capital is a form of value associated with culturally authorized tastes, consumption patterns, attributes, skills, and awards. Within the field of education, for example, an academic degree constitutes cultural capital (Webb, 2002, p.x).

Social capital, is a network of relationships among the members of a group which provides the members with some values and credit

The aggregate of the actual or potential resources which are linked to possession of a durable network of more or less institutionalized relationships of mutual acquaintances and recognition - or in other words, to membership in a group which provides each of its members with the backing of the collectively owned capital, a 'credential' which entitles them to credit, in the various senses of the word. (Bourdieu, 1979, p.21)

In linguistic capital, language as a means of creating power can shape the identity of the characters and is regarded as a value by Bourdieu. "The more linguistic capital the speakers possess, the more they are able to exploit the systems of 
differences to their advantage and thereby secure a profit of distinction". (Thompson, 1991, p.18) Language for Bourdieu is a mechanism of power:

Bourdieu takes language to be not merely a method of communication, but also a mechanism of power. The language one uses is designated by one's relational position in a field or social space. Different uses of language tend to reiterate the respective position of each participant. Linguistic interactions are manifestations of the participants' respective positions in social space and categories of understanding, and thus tend to reproduce the objective structures of the social field. This determines who has a 'right' to be listened to, to interrupt, to ask questions, and to what degree (Webb, 2002, p.3).

Symbolic capital is prestige, social status, fame and qualities which are not meaningful by themselves, but people believe that someone has them:

A form of capital or value that is not recognized as such. Prestige and a glowing reputation, for example, operate as symbolic capital because they mean nothing in themselves, but depend on people believing that someone possesses these qualities (Skeggs, 2004, p. 25).

Finally, economic capital, refers to money, land, house and other properties. The agents try to gain more properties to have a higher social status (Storey, 1990, p. xi).

Another term in Bourdieu's terminology is "Field", which he defines as a "dynamic" social space in which individuals struggle for a position or, in other words, for capital, like the field of education. Cultural field can be defined as "a series of institutions, rules, rituals, conventions, categories, designations and appointments which constitute an objective hierarchy and which produce and authorize certain discourses and activities." (Shusterman, 1999, p.18) Bourdieu also mentions the field of power as the space of relations of force between the agents or institutions to gain the dominant position in a field .

Habitus, as one of the main concepts of Bourdieu is described as "a system of durable dispositions; that is, as an internalized mental or cognitive structure that functions both consciously and unconsciously and constrains what people should and should not do." (Ihlen, 2009, p.65) Thus it is through habitus that the agents obtain certain manners, values and make an image for themselves in society.

"The physical attitudes and dispositions which emerge in individuals as a result of the relationships between particular fields and individuals' habits" is Bourdieu's definition for the term "bodily hexis." (Bourdieu, 1979, p.11) Bourdieu believes that people's disposition, way of standing, speaking, walking, feeling and thinking, that is, their body language, functions as distinction for people. For example, slow gestures are associated with noble class and too much haste and agitation with Bourgeoisie.

The last Bourdieusian term to be mentioned here is "misrecognition," which is the imposition of the dominant-class culture on subordinate groups. It is forced on agents by authority and the agents; it is a form of "symbolic violence," (Bourdieu, 1992, p.126) which the agents do not feel, that is, they consider all the limitations and denied-resources as natural, and therefore do not protest against it. For example, in a patriarchal society, female members may regard their status of being inferior to male ones as natural.

In Friel's Translations the dominant field is arguably that of education. The play is about a small community of Irish people, who live in Baile Beag village. A group of students with different age, sex and class from this village are trying to learn Irish, as well as Greek and Latin languages. The teacher, also the schoolmaster, is Hugh. Manus, Hugh's lame son also helps his father in teaching the village members. Owen, Hugh's other son, works as a translator for the English regiment which has the mission of renaming the Irish places and making a new map for Ireland. The English want to replace the Irish language with English claiming that Irish people will benefit from this replacement of language because they can do business and trade much more easily this way. Just a few members of this small Irish community see through the real motivation behind the English army's activities. At the end of the play, after the disappearance of English solider Yolland, the Irish are threatened to be evicted unless the English soldier is found and it is at this point that the English survey group's aim becomes known to all the Irish inhabitants .

As in every community, the members of this small community also compete to gain various capitals or values in the cultural, educational and social fields. The most important capital in the play in relation to most of the characters is cultural capital. Hugh, as the schoolmaster of the hedge-school community is the most respectable and cultured person in the cultural field of education. He has a knowledge of different languages such as Irish, English, Greek and Latin; therefore he has the highest status in the cultural field and all the other students try to improve their social position by learning these languages. In the process of the play he frequently declaims words or phrases in Greek or Latin and asks the students to translate them into Irish:

Hugh: Indeed- I encountered Captain Lancey of the Royal Engineers who is engaged in the ordnance survey of this are.... He explained that he does not speak Irish. Latin? I asked. None. Greek? Not a syllable. He speaks - on his own admission - only English and to his credit he seemed suitably verecund - James? Jimmy: Vercecundus - humble (I. 399).

At one level the use of classic languages - Greek, Latin and even Irish (related through the Celtic family of languages to Latin) - marks the 'distinction' between the teacher and the students culturally. However, at a more important level what is at stake here is a kind of cultural war, one between the colonizing English and the colonized Irish. The fact that Hugh emphasizes the English captain's ignorance of classic languages signals his attempt to depict him, and the English 
generally, as culturally inferior to the Irish with their Gaelic culture. In other words, Hugh astutely uses his people's cultural capital, or its myth, as a weapon against the colonizers. The English in turn are trying to take away this cultural weapon by changing the Gaelic names into English and making English the dominant language.

Hugh is highly respected for his cultural capital and the students in his school try to emulate him. The only student who is close to Hugh in possession of cultural capital is Jimmy Jack, a bachelor in his 60s. He comes to the evening classes partly for the company and partly for the "intellectual stimulation." (383) Jimmy believes in gods and ancient myths and is "fluent in Greek and Latin but is in no way pedantic." (384) Although he is nearly as knowledgeable as Hugh, he is not considered as a master as Hugh is, for Hugh has a special kind of prestige which is also partly due to his bodily hexis giving him a particular capital (symbolic capital) in the eyes of his students. Symbolic capital is "denied capital", it is a form of power "that is not perceived as power but as legitimate demands for recognition, deference, obedience or the services of others." (Swarts, 1997, p. 43) Prestige, fame, authority and alike are not meaningful by themselves; they are recognized as source of power when public opinion receives them as legitimate. Therefore the students regard some features in Hugh as prestigious, which lead to his cultural, social and symbolic capital. Jimmy Jack, however, fails to attract these kinds of capital.

Part of this capital that is given to Hugh is because of his particular gestures, body language, the way he talks, walks, etc. Although Hugh is often drunk, he is described in the stage directions as :

A large man, with residual dignity, shabbily dressed, carrying a stick. He has, as always, a large quantity of drink taken, but he is by no means drunk. He is in his early sixties (1.397).

Unlike Hugh Jimmy Jack who is almost as fluent in Greek and Latin as Hugh, is not as respectable as him. Because his appearance, body language and gestures mark him as a student rather than a teacher:

Jimmy Jack Cassie- known as the Infant Prodigy- sits by himself, contentedly reading Homer in Greek and smiling to himself. He is a bachelor in his sixties, lives alone, and comes to these evening classes partly for the company and partly for the intellectual stimulation. He is fluent in Latin and Greek but is in no way pedantic - to him it is perfectly normal to speak these tongues. He never washes. His clothes - heavy top coat, hat, mittens, which he wears now - are filthy and he lives in them summer and winter, day and night. He now reads in a quiet voice and smiles in profound satisfaction. For Jimmy world of the gods and the ancient myths is as real and as immediate as everyday life in the townland of Baile Beag (I.383). (emphasis added)

The point is that Jimmy, unlike Hugh, lacks the proper 'habitus' and 'bodily hexis' (generally part of habitus) associated with the 'field' of education; he neither looks nor sounds like a teacher. Crucially, he is not 'pedantic'.

Friel also uses different bodily gestures and poses to characterize his dramatis personae, to intimate their social status and power in the small Irish community. For instance, in Act I, Sarah is described as: "sitting on a low stool, her head down, very tense, clutching a slate on her knees." (Act 1, scene1) She is sitting on a lower stool than Manus, who is teaching her to speak. Her "speech defect is so bad that all her life she has been considered locally to be dumb and she has accepted this"(Act 1, scene1). As a male who is older than Sarah and has the ability to speak and also the ability to teach Irish, English, Greek and Latin, Manus in contrast has power over Sarah because of the factors of sex, age, social class and education. All these give him various kinds of capital; he has linguistic and social capital that has created symbolic capital for him.

The relationship between Manus and Sarah leads the reader to another Bourdieusian notion, that of 'misrecognition.' Sarah regards the superiority of Manus over herself as natural and does not object to it. In a larger context one can see this misrecognition about Irish people. The inhabitants of the village feel inferior to the English mostly because they speak English but the Irish cannot, that is, this ability has created a linguistic capital for the English soldiers. Also they are trained and have special ability in military services. Thus the Irish naturally accept the English dominance over themselves. Even when one of the villagers suggests that union and independence can save them, the idea is rejected and it is considered as impossible:

Doalty: If we'd all stick together. If we knew how to defend Ourselves.

Owen: Against a trained army (III. 442).

Owen, Hugh's second son who knows English and thus works as a translator for the English army, thinks of the English as very powerful and superior; to him they mean to help the Irish to improve and progress. At the beginning of the play, the reader sees that Owen translates Lancey's (the English Lieutenant) words to the benefit of the English rather than accurately. He depicts the English activities in their village as positive and explains that the English want to standardize the Irish map and help the people to improve their country:

Owen: And I'll translate as you go along.

Lancey: I see. Yes. Very well. Perhaps you're right. Well. What we are doing is this. (He looks at Owen. Owen nods reassuringly.) His Majesty's government has ordered the first ever comprehensive survey of this entire country - a general triangulation which will embrace detailed hydrographic and topographic information and which will be executed to a scale of six inches to the English mile.

Owen: The job is being done by soldiers because they are skilled in this work.

Lancey: And also so that the entire basis of land valuation can be reassessed for purposes of more equitable taxation.

Owen: This new map will take the place of the estate agent's map so that from now on you will know exactly what is yours in law (I. 406). 
Owen, the English translator, is after accumulating capital. By speaking English fluently (linguistic capital) he gets power over other Irish villagers. He is also connected with the soldiers who work in the English army (social capital). This leads to symbolic capital; that is, the Irish men consider a special rank for Owen and they trust him because they think he knows more than them and has more power. Owen, like other characters in the play, is also after economic capital and in fact his symbolic capital somehow paves the way to his economic success.

The reader should know that, Friel has used a theatrical technique to solve the linguistic issues at the heart of the play. As the critic Martine Pelletier declares, Baile Beag in 1833 would have been an Irish -speaking community, though some characters would also have been fluent in English. Yet the language the audience hears onstage throughout is English, except of course when it comes to the place names or some Latin and Greek words and quotations. Since the focus of the play is very much on language, its role in shaping and expressing personal and collective identity, the very fact that English onstage represents two separate languages - the Irish we are asked to imagine and the English which is now the "natural vehicle" for a play on an Irish stage - is immensely ironic and hugely significant (Pelletier, 2006, p.68).

In Act I, the interweaving of cultural issues, education, Irish history and identity, myths and language comes to the fore. The play starts with an educational field: Sarah and Manus in the hedge-school, with Manus trying to teach Sarah to speak. In the next part, after Hugh comes to the class, we see many Greek and Latin words and passages written by Hugh. Hugh also talks about publishing his book (as a cultural capital). Also, Jimmy Jack as an expert in Latin and Greek, frequently recites some passages from Homer, Virgil and other classical masters. Friel's focus, then, seems to be on cultural capital, but in the second and third Acts, culture becomes less prominent and it is replaced by economic capital, that is, money, property and wealth. Owen tells his father that he is earning a great deal of money for translating from English into Irish for the villager. Ironically, though he plays the role of a 'brown sahib,' 'house negro,' or 'comprador,' he feels proud and content.

Maire, the other character, who is Manus's beloved, is determined to climb socially through increasing her capitals. At the beginning of the play, Maire is blaming Manus because he has not applied for teaching at the new national school. The English have decided to close the Irish hedge-schools and substitute them with new national schools in which English is taught to the Irish. This is clearly an attempt to vanquish Irish culture and language to sustain the colonization of Ireland. Manus has rejected working in the new school as he is one of the few who are aware of the depth of the disaster.

Unlike Manus and like Owen, Maire is after economic capital. Looking down on her country's culture, she wishes to learn English; rehearsing the colonizers' ideology, this would be comprador says: "the old language is a barrier to modern progress." (400) To get a chance to learn English, she becomes intimate with one of the English soldiers, Yolland. In fact, she leaves Manus, who loves her truly, and goes to Yolland whose language she cannot understand. But Yolland's social status as an English soldier, his gestures and even his soft hands that she thinks are like gentlemen's, seduce Maire. In this respect, she is very much similar to Owen. Both are seduced by the symbolic capital of the colonizers.

By the end of the play, Yolland has disappeared and Lancey comes to the hedge-school threatening the villagers that he will destroy their village unless Yolland is found. It is at this point that most of the characters come to realize the real end of the English army. The reader finds that the close relation, the friendship or the marriage between two cultures which are miles away from each other is impossible. This impossibility is depicted through the relations of Owen and Maire with the English; the dream of friendship or marriage with the masters is shattered.

Friel artistically demonstrates this impossibility by using marriage as a metaphor. At the end of the play Jimmy Jack, the bachelor, who is interested in ancient gods and myths, asserts that he wants to marry Athene (the Greek goddess). When Maire talks about Yolland, Jimmy says:

Do you know the Greek word endogamein? It means to marry within the tribe. And the word exogamein means to marry outside the tribe. And you don't cross those borders casually- both sides get very angry. Now, the problem is this: Is Athene sufficiently mortal or am I sufficiently godlike for the marriage to be accepted to her people and to my people? You think about that (III. 446).

The parallelism that Friel has created in the image of marriage between tribes intimates the unfeasibility of the dream of union between two cultures, that of the colonizing and the colonized.

Brian Friel's play is obviously about culture or rather the clash of cultures. Of course a most relevant theorist here is Edward Said who has cogently theorized the crucial link between culture and imperialism. This paper argues for the relevance of another eminent theorist, that is, Pierre Bourdieu who has theorized how culture marks individuals socially. Friel's play illustrates this marking in the context of colonialism.

\section{REFERENCES}

[1] Bertha, C. (2006). Brian Friel as postcolonial playwright. In A. Roche (ed.), The Cambridge companion to Brian Friel. Cambridge: Cambridge University Press, 154-164.

[2] Bourdieu, P. (1979). Distinctions. R. Nice (trans.). London: Routledge.

[3] Bourdieu, P. (1992). The logic of practice. R. Nice (trans.). Stanford, CA: Stanford University Press.

[4] Friel, B. (1999). Two Plays. London: Faber and Faber.

[5] Oyvind, I. (2009). Public Relations in Field Struggles. In I. Oyvind, B. Van Ruler and M. Fredriksson(eds.), Public Relations and Social Theory. London: Routledge, 62-81. 
[6] Pelletier, M. (2006). Translations and the Field Day Debate. In A. Roche (ed.), The Cambridge companion to Brian Friel, Cambridge: Cambridge University Press, 66-77.

[7] Roche, Anthony. (2006). Cambridge Companion to Brian Friel. Cambridge: Cambridge University Press.

[8] Roche, A. (2006). Introduction. In A. Roche (ed.), The Cambridge companion to Brian Friel. Cambridge: Cambridge University, 1-5.

[9] Shusterman, R. (1999). Bourdieu: a critical reader. Cambridge: Polity Press.

[10] Skeggs, B. (2004). Context and background: Pierre Bourdieu's analyses of class, gender and sexuality." In L. Adkins and B. Sekggs (eds.), Feminism after Bourdieu. Oxford: Blackwell, 19-34.

[11] Storey, J. (1990). Cultural theory and popular culture. Harlow: Pearson.

[12] Swartz, D. (1996). Culture and Power. Chicago: The University of Chicago Press.

[13] Thompson, J. B. (1991). "Editor's Introduction" Language and the Symbolic Power (pp. 1-31). Cambridge: Polity Press.

[14] Webb, J., Schirato, T. and Danaher, G. (2002). Understanding Bourdieu. Australia: Allen and Unwin.

[15] Weber, J. J. (1998). Three models of power in David Mamet's Oleanna. In J. Culpeper, M. Short and P. Verdonk (eds.), Exploring the language of drama from text to context. London: Routlege, 112-127.

Hossein Pirnajmuddin is an Assistant Professor of English Literature at the University of Isfahan, Iran.

Elham Heidari is an MA student in English Literature at the University of Isfahan, Iran. 